\title{
Climate-Smart Agriculture: Rock Amendments
}

This fact sheet is the third installment of a four-part climate-smart agriculture series exploring the relationship between carbon farming, soil health, and soil amendments on CA croplands and rangelands. This fact sheet focuses on pulverized rock amendments and other fact sheets address the benefits of compost and biochar. The series is intended for members of the technical assistance community who advise CA growers on climate-smart agriculture.

\section{Pulverized rock as a soil amendment?}

For centuries farmers have been amending the soil with rock minerals to improve fertility. Rock minerals are rich in many of the nutrients that are needed to support healthy soils and can benefit soil water availability for crops. Some of the vital nutrients found naturally in rocks include calcium, magnesium, potassium and phosphorus, and micronutrients like zinc and iron. Recently, farmers have been exploring how different rock minerals can be applied to the soil to improve soil health, boost crop yields, and sequester $\mathrm{CO}_{2}$. The breakdown of rock, referred to as weathering, naturally consumes $\mathrm{CO}_{2}$ from the atmosphere through the weathering reactions of silicate minerals in the rock. When rock is pulverized into a powder, the reactive surface area increases which effectively speeds up the natural weathering process, leading to greater $\mathrm{CO}_{2}$ drawdown. Limited studies show that when some types of pulverized silicate rocks are applied to agricultural soils as amendments, they can provide co-benefits to growers in addition to sequestering carbon. ${ }^{1}$ Rock amendments may help mitigate climate change and provide a way for California to reduce greenhouse gas emissions. ${ }^{2}$ See this article for more information on current research trials.

\section{Enhanced weathering refers to increasing the rate of} rock breakdown by using higher surface area material, typically created by pulverizing rock into a powder. It is considered a carbon dioxide removal strategy.

Silicate rocks are crushed to facilitate greater weathering rates, and then applied as a soil amendment
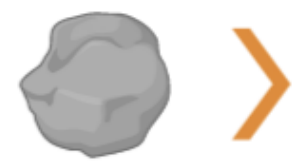

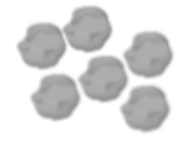

When rock weathers, it uses $\mathrm{CO}_{2}$ from the atmosphere

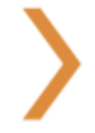

Essential plant nutrients are released into the soil as a result of rock weathering
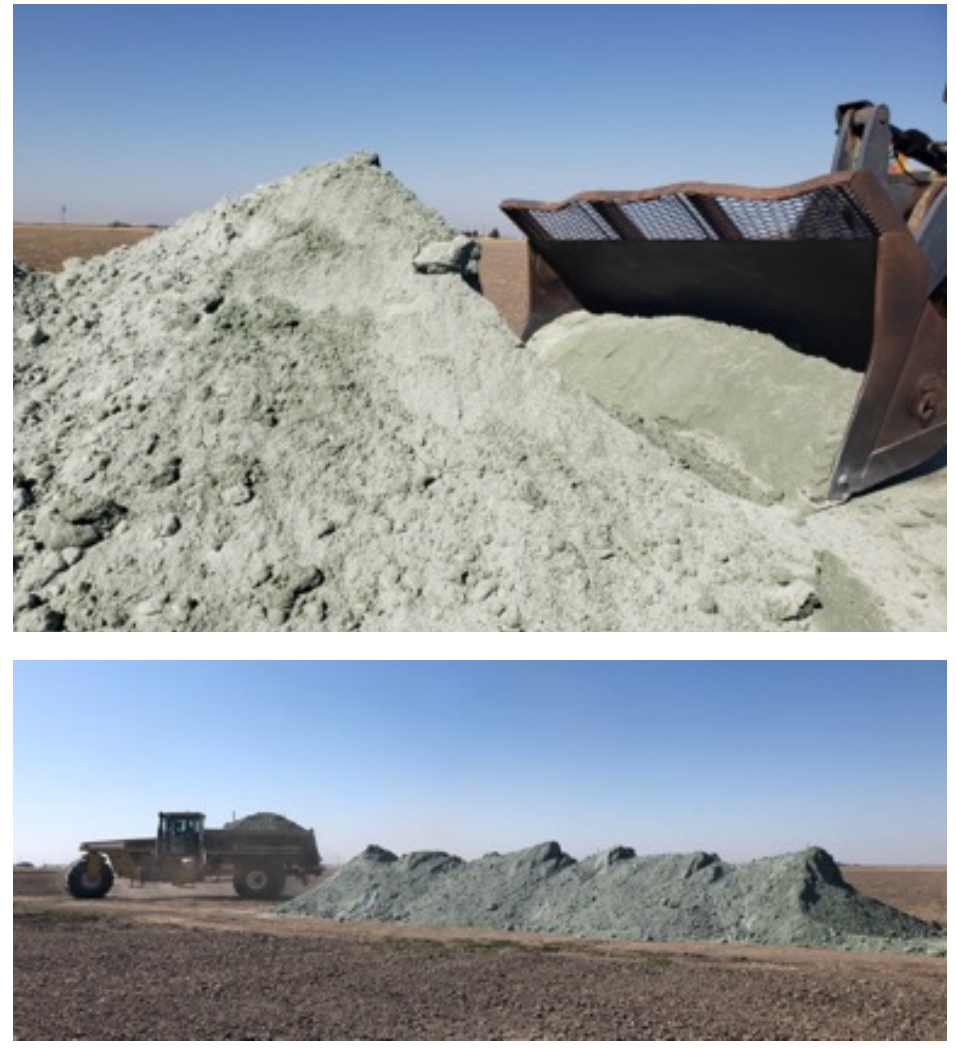

Rock amendment application on California fields. Images: Maya Almaraz and Iris Holzer, 2019

\section{How might rock amendments benefit growers?}

Nutrients are released into the soil when rock weathers. Silicate rocks such as basalt release nutrients like magnesium, calcium, and silicon which enhance soil fertility and support plant growth.1,3 By releasing nutrients into the soil and promoting plant growth, rock amendments may reduce the need for synthetic fertilizers and help to rebuild eroded soils. The illustration to the left depicts how pulverized rock may store carbon and release nutrients into the soil when applied as an amendment. Since many growers already apply granular fertilizers or lime to their fields, rock amendments can be applied using existing equipment. 


\section{What kind of rocks can be used as soil amendments?}

The Working Lands Innovation Center (WLIC) research focuses on silicate rocks, which are required for atmospheric $\mathrm{CO}_{2}$ removal but may also supply nutrients to the soil. WLIC uses basalt and meta-basalt as rock amendments; however, there are many different types of silicate rocks, each with different weathering rates ${ }^{4}$ and carbon sequestration potential. Additionally, different types of silicate rocks have the potential to release different macro- and micronutrients, making it critical to investigate which types of rock are best suited for each application site.

\section{How is carbon stored in the soil?}

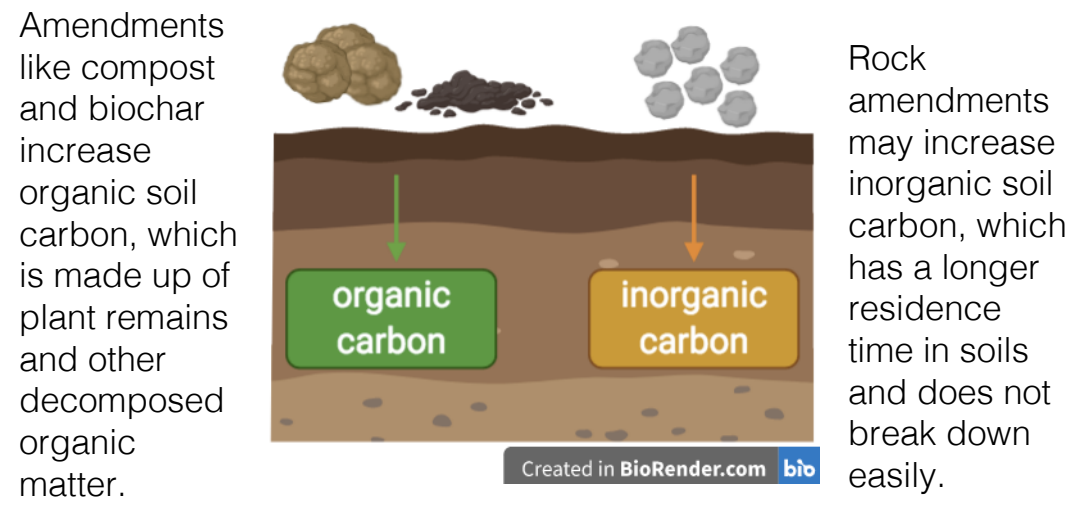

\begin{tabular}{c|c|c|c|}
$\begin{array}{c}\text { Where might rock } \\
\text { amendments have the } \\
\text { most benefit? Trials } \\
\text { suggest rock amendments } \\
\text { may have the largest } \\
\text { benefit for nutrient-poor or } \\
\text { highly weathered soils. }\end{array}$ & $\begin{array}{l}\text { Outstanding questions about } \\
\text { rock amendments }\end{array}$ \\
\hline $\begin{array}{c}\text { Are there potential risks for } \\
\text { growers? Certain types of } \\
\text { rock from mining }\end{array}$ & $\begin{array}{l}\text { While rock amendments hold promise for long-term } \\
\text { carbon sequestration in soils, there are } \\
\text { outstanding questions about the viability and more } \\
\text { field trials on the long-term impacts are critical. The } \\
\text { Working Lands Innovation Center is measuring the } \\
\text { byproducts may contain } \\
\text { heavy metals, which could } \\
\text { present risks if applied in } \\
\text { large amounts. }\end{array}$ & $\begin{array}{l}\text { different soil types and cropping systems in order } \\
\text { to understand how rock amendments may benefit } \\
\text { growers in California. }\end{array}$ \\
\hline
\end{tabular}

\begin{tabular}{|c|}
\hline $\begin{array}{c}\text { How do rock amendments } \\
\text { behave across different } \\
\text { soil types and cropping } \\
\text { systems? }\end{array}$ \\
\hline $\begin{array}{c}\text { How much silicate rock } \\
\text { amendments will be } \\
\text { available to growers in the } \\
\text { future? }{ }^{6}\end{array}$ \\
\hline $\begin{array}{l}\text { What are the trade-offs } \\
\text { between carbon } \\
\text { sequestration and co- } \\
\text { benefits for different types } \\
\text { of silicate rocks? }\end{array}$ \\
\hline
\end{tabular}

\section{Where can growers find more information?}

$>$ Energy Post article, enhanced weathering and rock amendments here

$>$ Eco Farming Daily article, basalt rock amendments here

$>$ Carbon Brief article, carbon storage potential and possible challenges here
The Working Lands Innovation Center (WLIC) aims to catalyze negative carbon emissions by deploying soil amendment technologies at multi-acre scales in partnership with California researchers, state agencies, industry, farmers, ranchers, Tribes and small-business development. See their website.

1. Kelland, M. E., et al. (2020). Global Change Biology, 26(6), 3658-3676. doi:10.1111/gcb.15089; Beerling, D. J., et al. (2018). Nature Plants, 4(3), 138-147. doi:10.1038/s41477-018-0108-y; Hartmann, J., et al. (2013). Reviews of Geophysics, 51(2), 113-149. doi:10.1002/rog.20004

2. Kantola, I. B., et al. (2017). Biology Letters, 13(4), 20160714. doi:10.1098/rsbl.2016.0714; Schuiling, R. D., et al. (2006). Climatic Change, 74(13), 349-354. doi:10.1007/s10584-005-3485-y

3. Berge, H. F., et al. (2012). PLoS ONE, 7(8). doi:10.1371/journal.pone.0042098; Guntzer, F., et al. (2011). Agronomy for Sustainable Development, 32(1), 201-213. doi:10.1007/s13593-011-0039-8

4. White, A. (2003). Treatise on Geochemistry, 133-168. doi:10.1016/b0-08-043751-6/05076-3

5. Anda, M., et al. (2015). Catena, 124, 147-161. doi:10.1016/j.catena.2014.09.012; Edwards, D. P., et al. (2017). Biology Letters, 13(4), 20160715. doi:10.1098/rsbl.2016.0715; Gillman, G. P. (1980). Soil Science Society of America Journal, 44(3), 465-468.

doi: 10.2136/sssaj1980.03615995004400030005x

6. Renforth, P., et al. (2011). Environmental Science \& Technology, 45(6), 2035-2041. doi:10.1021/es103241w

\section{John Muir Institute}

This fact sheet was developed by the USDA Climate Hub and the Working Lands Innovation Center. Any errors or omissions are the responsibility of the authors and can be directed to the USDA California Climate Hub. The lead author is Emilie Winfield, a graduate student researcher at UC Davis and the USDA CA Climate Hub, with input from Steven Ostoja (USDA CA Climate Hub). Thank you to Nina Bingham (UC Davis), Iris Holzer (UC Davis), and Benjamin Houlton (UC Davis) for serving as reviewers. For fact sheets on other topics related to CA agriculture, please visit https://www. climatehubs. usda.gov/hubs/California. 